\title{
Konservasi Air dan Energi dengan Menghidupkan Sunnah Nabi
}

\author{
Mujahidin Ahmad \\ Jurusan Biologi \\ Fakultas Sains dan Teknologi \\ Universitas Islam Negeri Maulana Malik Ibrahim Malang \\ Email: mujahidin@bio-uin.ac.id
}

\begin{abstract}
Islam is a universal religion. Not only governs the relationship between servant and God but also regulates the relationship with fellow beings. Among the teachings of Islam that governs the relationship with the creatures is how the adherents of Islam set to be considerate of the environment, ie, how should humans maintain balance of nature and not ruin it. The use of water and energi, including matters governed by Islam through the Qur'an and the instructions Prophet Sallallaahu 'alaihi wasallam. Instructions regarding the procedure of which the Prophet made ablution, bathing, brushing teeth closely related to water conservation, while the doctrine of fasting, to walk to the mosque, turn off a light during sleep so strongly associated with the doctrine of the conservation of energy. By following the Sunnah of a Moslem not only to be rewarded, but also contribute to the conservation of natural resources whose benefits will be felt by all mankind.
\end{abstract}

Key word : Islam, prophet tradition, conservation, water, energy

\section{PENDAHULUAN}

Islam adalah agama terbesar, bukan saja hanya berdasarkan jumlah penganutnya yang mencapai $22.43 \% \quad(1.574 .997 .821$ jiwa) dari seluruh populasi dunia sebanyak 7.021.836.029 jiwa pada tahun 2013 (Muadz, 2014) namun juga karena esensi ajarannya yang universal (syaamil) dan sempurna (kaamil). Kesempurnaan dan keuniversalan agama Islam tersebut sebagaimana difirmankan Allah subhanahuwata'ala dalam Q.S. Al Maa'idah potongan ayat 3 , yang berbunyi:

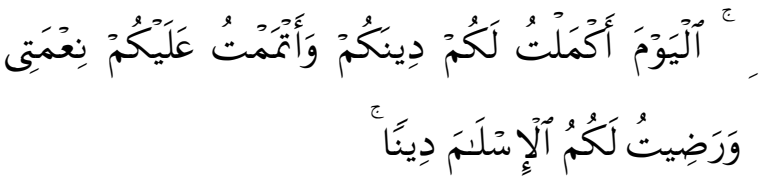

Artinya; "...Pada hari ini telah Kusempurnakan untuk kamu agamamu, dan telah Ku-cukupkan kepadamu nikmat-Ku, dan telah Ku-ridhai Islam itu jadi agama bagimu..."

Diantara bukti kesempurnaan Islam adalah bahwa Islam tidak hanya mengatur hubungan antara Sang Pencipta (Al-Khaliq) dengan makhluk, tetapi lebih dari itu Islam juga mengatur dengan sangat gamblang bagaimana hubungan antar sesama makhluk (Al-Jazairi,
2010). Imam Bukhari meriwayatkan dalam Shahih-nya dari Hudzaifah radhiyallahu 'anhu, ia berkata: "Sungguh Nabi shallallahu alaihi wasallam berkhutbah di hadapan kami dengan suatu khutbah yang beliau tidak meninggalkan sedikitpun perkara yang akan berlangsung sampai hari kiamat kecuali beliau sebutkan ilmunya" (Shahih Bukhari, No. Hadits: 6604). Demikian Juga beliau Shallallahu 'alaihi wa sallam juga bersabda,

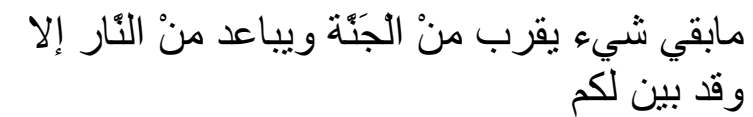

Artinya; "Tidak tersisa suatu (amalan) pun yang dapat mendekatkan kepada surga dan menjauhkan dari neraka, kecuali sudah dijelaskan semuanya kepada kalian". (HR. Thobroni dalam Al Mu'jamul Kabir 1647, dishohihkan oleh Syaikh Ali Hasan Al Halabi)

Dalam masalah yang sepelepun Islam juga mengaturnya. Hal ini sebagaimana sebuah kisah ketika seorang dari kaum musyrikin berkata kepada Salman Al-Farisi, "Apakah Nabimu mengajarkan segala sesuatu kepada kalian sampai pada masalah buang air?" Maka Salman menjawab, "Benar, beliau telah 
melarang kami dari menghadap kiblat ketika buang air besar maupun kecil ..." - sampai akhir hadits" (Tafsir al-Qur'an al-"Azhim Ibnu Katsir (4/156)). Aturan-aturan Ilahi tersebut disepakati bersumber dari 2 sumber utama, yaitu Kitab Suci Al-Qur' an dan Al-Hadits atau Tradisi Kehidupan Nabi (Sunnah Nabi), sebagaimana dalam sabda Nabi: "Telah kutinggalkan untuk kalian dua perkara yang (selama kalian berpegang teguh dengan keduanya) kalian tidak akan tersesat, yaitu Kitabullah (Al-Quran) dan Sunnah-ku.” (HR. Hakim dan Daruquthni). Al Quran dikenal sebagai kitab suci yang menjelaskan permasalahan dan hukum-hukum secara umum (Mujmal) sedangkan al Hadits (Sunnah Nabi) berfungsi menjelaskan yang mujmal tersebut menjadi terperinci (Tafshili).

Tujuan diturunkannya Al-Qur'an dan Hadits adalah sebagai pemecahan masalah umat manusia. Diantara masalah-masalah yang saat ini terjadi adalah peningkatan jumlah penduduk yang tidak terbendung mengakibatkan meningkatnya pula kebutuhan manusia akan sumber daya air dan energi. Ketersediaan air bersih dan juga energi tidak terbarukan semakin hari semakin menurun akibat eksploitasi dan penggunaan yang melampaui batas. Diperkirakan bahwa saat ini lebih dari 1.1 miliar orang tidak memiliki akses terhadap air minum bersih atau sekitar seperenam dari populasi dunia. Setengah dari anak yang lahir di negara berkembang akan tinggal di rumah yang tidak memiliki akses terhadap air (Ahmad, 2011).

Dalam Islam, air adalah salah satu benda di muka bumi yang sangat penting, diantara ayat yang paling terkenal berkaitan dengan air adalah Firman Allah dalam Q.S. Al Anbiya ayat 30;

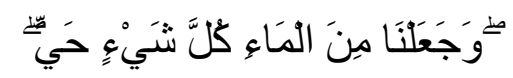

Artinya; "...dari air Kami jadikan segala sesuatu yang hidup...".

Namun ayat ini bukan satu-satunya ayat di mana kata $M \bar{a}$ '(air) muncul, bahkan lebih dari enam puluh kali (63 kali) dalam al-Quran katakata air disebutkan (Wickström, 2010). Sedangkan kata lain yang berkaitan dengan air dan hidrologi, diantaranya seperti sungai, laut, air mancur, mata air, hujan, es, awan, dan angin juga disebutkan dalam Al-Qur'an (Haleem, 1989 dan Gilli, 2002).

Pemecahan masalah ketersediaan air dan energi harus dilakukan dengan pendekatan yang komprehensif berdasarkan tingkat kebutuhan dan penyediaan yang berkelanjutan. Hal ini perlu dilakukan sebuah upaya pemecahan keterbatasan penyediaan air bersih rumah tangga dengan cara mengatur dan mengubah perilaku penduduk dalam mengkonsumsi air. Oleh karena itu agama masih memberikan pengaruh yang sangat besar terhadap perilaku masyarakat dan juga karena air memiliki peran yang sangat penting dalam Islam, kampanye kesadaran dan program konservasi air berdasarkan prinsipprinsip agama telah terbukti sangat berguna, menguntungkan dan dengan biaya yang efektif sebagaimana diterapkan di berbagai wilayah dunia Islam (Gilli, 2002).

Diantara Sunnah Nabi yang berhubungan dengan konservasi air dan energi adalah dengan memberikan pengetahuan kepada masyarakat, muslim khususnya, untuk melihat bagaimana perilaku dan ajaran Rasulullah Shallallahu alaihi wasallam terhadap air dan energi yang kesemuanya itu jika dibahas akan memberikan pemahaman bahwa setiap ajaran Rasul memiliki hikmah dan faedah yang sangat besar bagi kehidupan makhluk di dunia. Dengan menghidupkan tradisi kehidupan Nabi yang terekam dalam hadits-hadits yang shahih tersebut maka diharapkan umat Islam sebagai umat dengan populasi terbesar di dunia dapat memberikan kontribusi dan manfaat yang nyata bagi kehidupan makhluk di bumi, yaitu bijak dalam memanfaatkan air dan energi. Berikut akan dibahas tentang beberapa tradisi kehidupan Nabi (Sunnah nabawiyyah) yang berkaitan dengan air dan energi:

\section{Berhemat dalam Berwudhu dan Mandi}

Menurut Arika (2007), jumlah konsumsi air bersih untuk setiap keperluan rumah tangga di Indonesia adalah MCK (Mandi Cuci Kakus) sebesar 57.53\%, wudhu $14.60 \%$, mencuci pakaian $11.17 \%$, memasak $9.01 \%$, menyiram tanaman $4.33 \%$, kebersihan rumah $3.73 \%$, mencuci kendaraan $2.46 \%$, mengisi kolam atau akuarium $1.75 \%$, dan minum $1.3 \%$.

Fenomena yang terjadi pada umat Islam pada umumnya, kebutuhan air untuk berwudhu sangat besar. Berdasarkan Nurmiyanto (2012) kebutuhan air untuk berwudhu orang Indonesia diperkirakan sekitar 3 liter/1 kali wudhu, sehingga dibutuhkan air sebanyak 15 liter/hari untuk lima kali shalat. Hal ini disebabkan sebagian besar muslimin berada pada daerah surplus air dan tidak memperhatikan tentang tata cara wudhu yang benar dan tidak memperhatikan 
pentingnya penghematan air melalui wudhu. Sebagian besar mereka boros dan mubazir dalam penggunaan air, padahal Allah Subhanahu wata'ala berfirman dalam potongan ayat yang artinya: “...janganlah kamu berlebih-lebihan. Sesungguhnya Allah tidak menyukai orang yang berlebihlebihan" (QS. Al-An'am : 141)

Padalah jika tata cara berwudhu kaum muslimin mengikuti cara wudhunya Rasulullah Shalallahu 'alaihi wasallam maka akan dapat menghemat pengeluaran air secara signifikan. Hal ini dikarenakan Nabi Shallallahu 'alaihi wasallam mengajarkan untuk berwudhu dengan sangat hemat, yaitu menggunakan air sebanyak 1 mud saja atau setara dengan cakupan dua telapak tangan dewasa dalam 1 kali wudhu, hal ini sebagaimana hadits shahih: "Bahwasanya Nabi Shalallahu 'alaihi wasallam biasa berwudhu dengan 1 mud (1 genggaman tangan orang Arab zaman Nabi) air dan mandi dengan 4 sampai 5 mud air." (H.R. Al Bukhari no. 201, Muslim no. 325, menurut lafazh Muslim). Satu mud menurut para ahli fikih dikonversikan menjadi sejumlah 0.6875 liter air (Zuhaili dalam Al-Jazairi, 2010 dan Majalah an Nashihah, Vol. 11, Tahun 1427H/2006 M, hal. 37-39). Artinya setiap muslim maksimal hanya membutuhkan sekitar 3.5 liter air bersih untuk berwudhu dalam satu hari.

Namun ada pertanyaan, bukankah Rasulullah Shalallahu 'alaihi wasallam berwudhu dengan seperti itu dikarenakan beliau hidup di tanah yang gersang (arab), maka hadits berikut jawabannya:

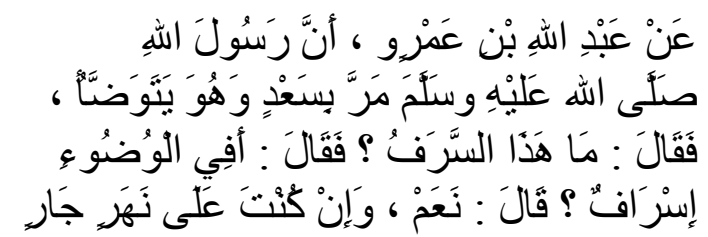

Dari Abdullah bin Amr Radliyallahuanhuma sesungguhnya Nabi Shallallahu 'alaihi wasallam melewati Sa'ad (bin Abi Waqqosh Radliyallahu anhu) sedang berwudhu, maka beliau bersabda kepadanya: "Janganlah boros (dalam penggunaan air)”, maka beliau (Sa'ad) berkata, "Apakah dalam (masalah) air ada pemborosan?", beliau-Shallallahu 'alaihi wasallam- bersabda, "Iya, walaupun kamu berada di sungai yang mengalir" (H.R. Ibnu Majah 1: 272).
Sebagai bentuk larangan berlebihlebihan dalam berwudhu, Rasulullah Shalallahu 'alaihi wasallam juga melarang untuk melakukan basuhan anggota wudhu lebih dari 3 kali (H.R. An-Nasai no. 140, Ahmad no. 6646 dan Ibnu Majah no. 422 dalam Al-Jazairi, 2010), dan diperbolehkan hanya membasuh 1 kali saja sebagaimana hadits hasan shahih riwayat Abu Dawud no. 124, Fathul Baari no. 158, Aunul Ma'bud I:230 dan Tirmidzi I:31 no. 34 dari hadits Abu Hurairah Radliyaallahu'anhu (AlKhalafi, 2011). Demikian juga sebuah hadits yang kuat Rasulullah Shalallahu 'alaihi wasallam bersabda:

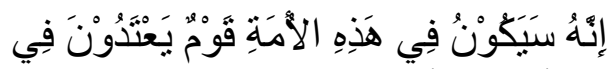

$$
\begin{aligned}
& \text { الطُهُوز وَالأدُعَاءِ }
\end{aligned}
$$

Artinya; "Akan ada orang-orang dari umat ini yang melampui batas dalam berwudhu dan berdoa." (H.R. Abu Dawud dengan sanad yang kuat menurut Syaikh Syu'aib alArnauth).

Diantara cara paling mudah untuk berwudhu dengan hemat dan sesuai Sunnah Rasul adalah dengan menggunakan gayung atau ember, mengambil air darinya untuk mengusap anggota wudhu dengan tangan kanan sesuai kebutuhan (Ahmad, 2011). Hal ini berbeda jika menggunakan kran air yang lebih sulit untuk mengontrol penggunaan air secara hemat. Diantara bentuk lain konservasi air adalah sebagaimana dijelaskan Nurmiyanto (2012) yang menyatakan tentang bolehnya penggunaan air daur ulang wudhu untuk konsumsi atau bersuci asal telah melalui prosedur fikih yang benar sebagaimana Fatwa Majelis Ulama Indonesia No. 02 Tahun 2010 Tentang Air Daur Ulang.

\section{Menggosok Gigi dengan Siwak}

Termasuk Sunnah yang paling sering dan yang paling senang dilakukan oleh Rasulullah Shallallahu 'alaihi wa sallam adalah bersiwak. Bersiwak atau menggosok gigi dengan kayu pohon arak (Salvadora persica) merupakan pekerjaan yang sederhana dan ringan, tetapi memiliki manfaat yang sangat banyak baik bersifat keduniaan yaitu berupa kebersihan mulut, sehat, segar, putihnya gigi, menghilangkan bau mulut, dan lain-lain, maupun manfaat- 
manfaat yang bersifat akhirat, yaitu ittiba' (mengikuti) kepada Nabi Shallallahu 'alaihi wa sallam dan mendapatkan keridhaan dari Allah Subhanahu wata'ala. Sebagaimana sabda Rasulullah Shallallahu 'alaihi wa sallam:

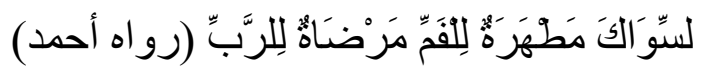

Artinya; "Siwak merupakan kebersihan bagi mulut dan keridhaan bagi Rabb". (H.R. Ahmad, dalam Irwaul Ghalil no. 66 dan Syarhul Mumti' 1/120 dan Taisir 'Alam 1/62)

Bahkan Rasulullah Shallallahu 'alaihi wasallam jika seandainya tidak ingin memberatkan umatnya, beliau akan memerintahkan (mewajibkan) umatnya untuk bersiwak. Hal ini sabda Rasulullah Shallallaahu 'alaihi wasallam,

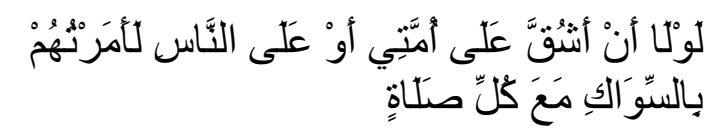

Artinya; "Kalau saja aku tidak khawatir memberatkan umatku, niscaya telah aku perintahkan mereka bersiwak pada setiap kali shalat" (H.R. Bukhori, Muslim, Malik no. 147, Shahihul Jami no. 5316, AlFathur Robani I:294 no. 171)

Penggunaan siwak sebagai bahan dan alat gosok gigi telah terbukti ilmiah memiliki khasiat untuk mencegah kerusakan dan penyakit pada gigi. Kandungan yang ada dalam ranting pohon arak telah diteliti memiliki kandungan minyak esensial yang dapat merangsang aliran saliva di dalam rongga mulut. Hal ini dapat menghambat penurunan $\mathrm{pH}$ plak karena di dalam saliva terdapat bufer bikarbonat yang merupakan pertahanan efektif terhadap produksi asam dari bakteri kariogenik. Siwak juga memiliki efek bakterisida terhadap beberapa bakteri yang terdapat di dalam plak sehingga metabolisme makanan oleh bakteri tidak terjadi dan produk asam tidak terbentuk sebagai antimikroba alami yang ada di mulut (Al-Bayati dan Sulaiman, 2008; Adriyati, 2011).

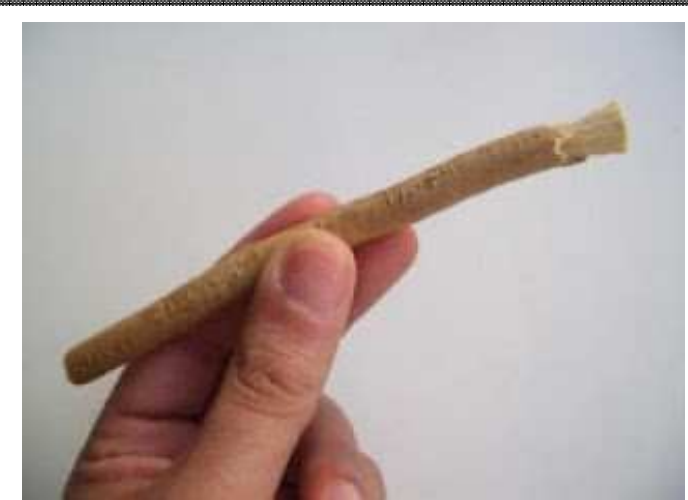

Gambar 1. Kayu siwak untuk pembersih gigi

Chlorhexidine glukonat (CHX) adalah salah satu agen anti-plak terbaik yang terbukti terdapat di kayu siwak (Almas, 2002), Bahkan penelitian Al Bayati dan Sulaiman (2007) menunjukkan bahwa ekstrak air dan metanol dari pohon siwak memiliki aktivitas antimikroba dan mampu menghambat pertumbuhan 7 bakteri pathogen yang terisolasi di mulut yaitu Staphylococcus aureus, Streptococcus mutans, Streptococcus faecalis, Pyogenis streptococcus, Lactobacillus acidophilus, Pseudomonas aeruginosa, dan Candida albicans. Sedangkan penelitian Ahmad dan Rajagopal (2013) membuktikan bahwa kandungan siwak seperti flavonoid, salvadorine, glikosida sianogen, lignan, saponin, alkaloid, tanin, asam linoleat, asam stearat, salvadourea, vitamin C, silika dan garam yang berbeda juga diketahui memiliki aktivitas antimikroba yang signifikan, antiplak, afrodisiak, alexiteric, analgesik, antiinflamasi, anti-piretik, astringent, dan mual. Almas dan Zeid (2004) melaporkan bahwa kandungan siwak seperti Chloride dan silika merupakan bahan pengangkat plak dan pembersih gigi, tannin, dan resin membentuk lapisan pelindung pada email yang mencegah masalah kerusakan gigi, vitamin $\mathrm{C}$, dan trimetyl amine membantu dalam menyembuhkan jaringan gigi. Trymetyl amine berfungsi dalam mengurangi kalkulus dan stain, sulfur, alkaloid dan fluor melindungi gigi dari bakteri kariogenik.

Disamping sudah teruji manfaat medisnya, siwak juga memiliki kelebihan yang tidak dimiliki oleh sikat dan pasta gigi modern, diantaranya siwak lebih ramah lingkungan, murah, masa pakai yang relatif lama, praktis, dan efisien dalam menghambat pertumbuhan bakteri sebagaimana tercantum dalam tabel 1 . 
Tabel 1. Perbandingan penggunaan siwak dan pasta gigi dengan sikat gigi modern

\begin{tabular}{|c|c|c|}
\hline $\begin{array}{l}\text { Pembandin } \\
\text { g }\end{array}$ & Siwak & $\begin{array}{l}\text { Sikat dan } \\
\text { Pasta Gigi }\end{array}$ \\
\hline Bahan & $\begin{array}{l}\text { Alami, } \\
\text { tanpa } \\
\text { limbah } \\
\text { kimia }\end{array}$ & $\begin{array}{l}\text { Sintetis, } \\
\text { menghasilkan } \\
\text { limbah kimia } \\
\text { berupa } \\
\text { cairan, plastik } \\
\text { sikat gigi, } \\
\text { kemasan } \\
\text { plastik dan } \\
\text { karton }\end{array}$ \\
\hline Harga & $\begin{array}{l}\text { Relatif } \\
\text { murah }\end{array}$ & Relatif mahal \\
\hline Masa pakai & Lama & Sebentar \\
\hline $\begin{array}{l}\text { Praktis dan } \\
\text { efisien }\end{array}$ & $\begin{array}{l}\text { Praktis, } \\
\text { tidak } \\
\text { membutuhk } \\
\text { an air }\end{array}$ & $\begin{array}{l}\text { Tidak praktis, } \\
\text { membutuhka } \\
\mathrm{n} \text { air dalam } \\
\text { penggunaann } \\
\text { ya }\end{array}$ \\
\hline $\begin{array}{l}\text { Daya } \\
\text { hambat } \\
\text { (rerata lebar } \\
\text { zona } \\
\text { inhibisi) } \\
\text { terhadap } \\
\text { bakteri } \\
\text { Streptococc } \\
\text { us mutans } \\
\text { (Pratiwi, } \\
\text { 2005) }\end{array}$ & $25.48 \mathrm{~cm}$ & $19.79 \mathrm{~cm}$ \\
\hline
\end{tabular}

\section{Menjilat Makanan}

Diantara Sunnah Nabi yang sudah banyak ditinggalkan saat ini adalah menjilati tangan dan piring setelah selesai makan sebelum mengelap atau mencucinya, sunnah ini menurut sebagian orang menjijikkan dan kuno, padahal banyak sekali manfaat yang didapat dalam menjalankan sunnah ini. Hal ini sebagaimana sabda Rasulullah Shallallahu 'alaihi wasallam:

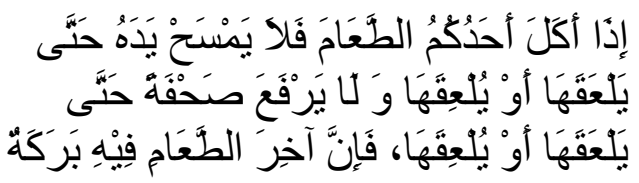

Artinya; "Apabila salah seorang kamu makan makanan, janganlah dia mengelap tangannya hingga menjilatinya atau meminta orang menjilatinya. Dan janganlah dia mengangkat piringnya hingga menjilatinya atau meminta orang untuk menjilatinya., karena pada makanan terakhir terdapat barakah." (H.R. Bukhari no. 5465; Muslim no. 2031, Abu Dawud, AnNasai, Ahmad dan lainnya, hadits shahih dalam al-Silsilah alShahihah: 1/675)

Diantara hikmah yang didapat dalam menjilati makanan adalah:

a. Mendapatkan barakah makanan sebagaimana hadits muttafaqun alaih diatas

b. Tidak meremehkan makanan walaupun sedikit, karena Islam sangat menghargai makanan dan mencela orang yang bersikap mubazir sebagaimana firmanNya:

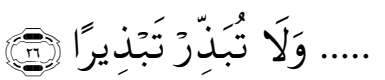

Artinya; “... janganlah kamu menghambur-hamburkan (hartamu) secara boros".

Dan diantara keborosan atau tabdzir adalah dengan menyia-nyiakan makanan kita.

c. Membantu proses pencernaan makanan di lambung

Syaikh Ibnul Utsaimin dalam Syarh Riyadhus Shalihin mengungkapkan: "Ada orang yang menyampaikan informasi kepadaku yang bersumberkan dari keterangan salah seorang dokter, bahwa ruas-ruas jari tangan ketika digunakan untuk makan itu mengeluarkan sejenis cairan yang membantu proses pencernaan makan dalam lambung. Seandainya informasi ini benar maka ini adalah di antara manfaat mengamalkan Sunnah di atas. Jika manfaat secara medis tersebut memang ada, maka patut disyukuri. Akan tetapi jika tidak terjadi, maka hal tersebut tidaklah menyusahkan kita karena yang penting bagi kita adalah melaksanakan perintah Nabi." (Syarah Riyadhus Shalihin Juz VII hal 243-245)

d. Dengan menjilat makanan secara otomatis mengurangi volume sampah organik, menghemat air, dan deterjen dalam proses cuci tangan. 


\section{Berjalan kaki ke masjid}

Umat Islam diwajibkan untuk melaksanakan sholat berjamaah di masjid sebanyak 5 kali sehari, khususnya untuk lakilaki (Al-Khalafi, 2011). Kenyataan di lapangan banyak diantara mereka yang menggunakan kendaraan bermotor untuk pergi ke masjid walaupun jarak yang ditempuh tidak terlalu jauh. Padahal tuntunan Nabi Shallallahu 'alaihi wasallam yang sebenarnya menganjurkan agar pergi ke masjid dengan jalan kaki, baik ketika shalat wajib sebagaimana dalilnya :

Dari Abu Musa katanya; Rasulullah Shallallahu 'alaihi wasallam bersabda:

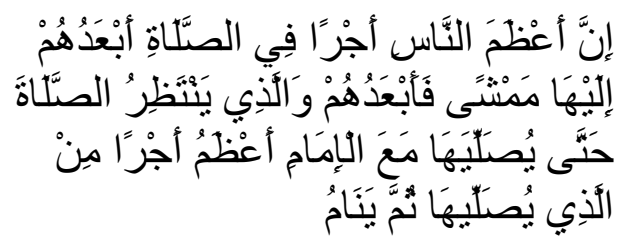

Artinya; "Manusia paling besar pahalanya dalam shalat adalah yang paling jauh perjalannya, lalu yang selanjutnya. Dan seseorang yang menunggu shalat hingga melakukannya bersama imam, lebih besar pahalanya daripada yang melakukannya (sendirian) kemudian tidur." (H.R. Muslim no. 662)

Bahkan, sebenarnya pejalan kaki ke masjid akan mendapatkan pahala yang sangat banyak sebagaimana hadits dari Ubay bin Kaab Radliyallahu'anhu dia berkata: "Ada seorang dari golongan sahabat Anshar yang saya tidak mengetahui seseorang pun yang rumahnya lebih jauh letaknya dari rumah orang itu jikalau hendak ke masjid, tetapi ia tidak pernah terlambat oleh sesuatu shalat (yakni setiap shalat fardhu ia selalu mengikuti shalat berjamaah)". Lalu dikatakan kepadanya, "Alangkah baiknya jikalau engkau membeli seekor keledai yang dapat engkau naiki di waktu malam gelap gulita serta di waktu teriknya panas matahari." Dia menjawab, "Saya tidak senang kalau rumahku itu ada di dekat masjid, sesungguhnya saya ingin kalau jalanku sewaktu pergi ke masjid dan sewaktu pulang dari masjid untuk kembali ke tempat keluargaku itu dicatat pahalanya untukku." Maka Rasulullah bersabda, "Allah telah mengumpulkan untukmu pahala kesemuanya itu (yakni waktu pergi dan pulangnya semuanya diberi pahala karena langkah kakinya)". (H.R. Muslim)

Jika umat Islam mau melaksanakan sunnah ini niscaya penghematan energi akan terjadi secara signifikan. Disamping itu pejalan kaki akan mendapatkan manfaat kesehatan dari hasil olahraga secara rutin lima kali sehari.

\section{Berpuasa}

Salah satu ibadah yang sarat dengan kebaikan dan kemaslahatan adalah shaum (puasa). Kemaslahatan puasa ini tidak terbatas pada tempat dan waktu, ia menembus segala masa. Karenanya, hikmah Allah menuntut diberlakukannya puasa kepada semua umat, umat ini dan umat-umat sebelumnya. Firman Allah Ta'ala :

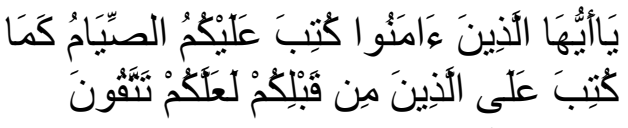

Artinya; "Hai orang-orang yang beriman, diwajibkan atas kamu berpuasa sebagaimana diwajibkan atas orang-orang sebelum kamu agar kamu bertakwa." (Al-Baqarah: 183).

Dari Abu Said Al-Khudri radhiallahu anhu dia berkata: Rasulullah Shallallahu alaihi wasallam bersabda: "Tidaklah seorang hamba berpuasa sehari di jalan Allah, kecuali Allah akan menjauhkan wajahnya dari api neraka sejauh tujuh puluh ribu musim." (H.R. Al-Bukhari no. 2628 dan Muslim no. 1153)

Berpuasa tidak hanya baik untuk kesehatan namun juga memberikan manfaat bagi alam. Puasa dapat menjadikan manusia memiliki perisai akan kebutuhan hidupnya. Nabi berkata :

$$
\text { آلصنَّومُ جُنَّة }
$$

Artinya; "Puasa itu adalah perisai." (H.R. Al-Bukhari dan Muslim, dari Abu Hurairah, Mukhtashar shahih AlBukhari, no. 871 dan Mukhtashar Shahih Muslim, no. 571). 
Makna "perisai" disini bukan hanya sebatas perlindungan dari segala bentuk perbuatan dosa dan kesia-siaan, namun juga "perisai" manusia terhadap makanan, minuman, serta konsumsi yang berlebihan.

Hossain (2012) menjelaskan bahwa selain memberikan manfaat secara fisik, emosional dan spiritual, puasa dapat memberikan manfaat secara ekonomi, termasuk pengurangan konsumsi makanan maupun pembelian barang yang tidak berguna. Hal ini menunjukkan bahwa dengan puasa, umat Islam ikut memberikan kontribusi terhadap penghematan anggaran dan energi.

\section{Tidur lebih dini dan mematikan lampu dikala hendak tidur}

Menurut Departemen Energi dan Sumber Daya Mineral (ESDM) RI, distribusi energi listrik di Indonesia diproyeksikan sebagai berikut; rumah tangga 33\%, bisnis/ perkantoran dan gedung komersial 30\%, sektor industri 30\% (kebanyakan di wilayah Tangerang), gedung pemerintahan $3 \%$, serta fasilitas publik dan sektor sosial 4\%. Dari data tersebut dapat diketahui bahwa sektor rumah tangga adalah sektor paling tinggi dalam konsumsi energi. Departemen ESDM juga menegaskan bahwa masalah pemborosan energi, secara umum sekitar $80 \%$ diakibatkan oleh faktor manusia dan $20 \%$ disebabkan oleh faktor teknis. Oleh karena itu, upaya terus menerus untuk menyadarkan manusia tentang pentingnya hemat energi sangat penting dilakukan.

Diantara upaya penghematan energi adalah dengan mematikan lampu ketika akan tidur. Sebagaimana ajaran Rasulullah Shallallahu 'alaihi wasallam dalam sabdanya:

Diriwayatkan dari Abi Barzah, beliau (Rasulullah Shallallahu 'alaihi wasallam) bersabda:

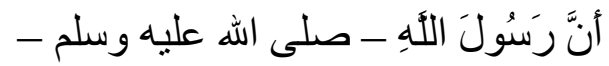

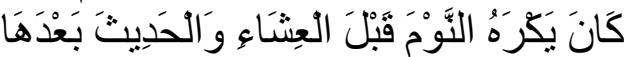

Artinya; "Rasulullah shallallahu 'alaihi wa sallam membenci tidur sebelum shalat 'Isya dan ngobrol-ngobrol setelahnya." (H.R. Bukhari no. 568)
Dari kutipan di atas menjelaskan bahwa Rasulullah Shallallahu 'alaihi wasallam tidak menyukai begadang yang tanpa arti (mengobrol), karena selain tidak membawa manfaat juga pemborosan waktu dan energi, karena begadang tidak mungkin dilakukan dalam keadaan lampu yang dimatikan.

Nabi Shallallahu 'alaihi wasallam juga bersabda dalam hadits shahih:

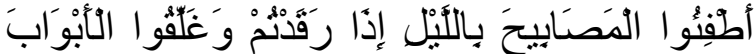

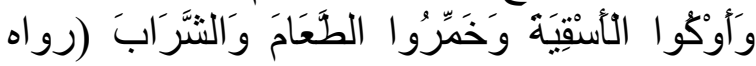

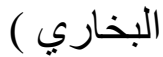

Artinya; "Padamkanlah lampu-lampu di malam hari pada saat kalian tidur di malam hari, kuncilah pintu dan tutuplah bejana, makanan dan minuman." (H.R. Al-Bukhari)

Dan dalam hadits yang lain Rasulullah Shallallahu 'alaihi wasallam bersabda:

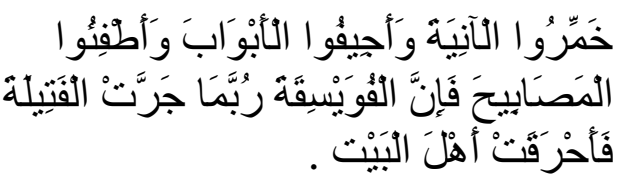

Artinya; "Tutuplah tempat air kalian, pintu rumah kalian, dan matikanlah lampu-lampu kalian, karena bisa jadi tikus akan menarik sumbu lampu sehingga mengakibatkan kebakaran yang menimpa para penghuni rumah." (H.R. AlBukhari)

Jika setiap rumah tangga melaksanakan sunnah ini, maka berpotensi untuk menghemat anggaran listrik, belum lagi menekan potensi konsleting akibat lalai ketika tidur dan juga kebakaran juga dapat dicegah.

Bukan hanya penghematan energi yang didapat, penelitian ilmiah menunjukkan bahwa salah satu cara terbaik untuk tidur adalah dengan mematikan lampu di sekitar kita, selain hemat energi, secara medis telah terbukti bahwa keadaan gelap dikala tidur akan membuat hormon tubuh bernama melatonin disekresikan dan bekerja secara maksimal (Hardeland et al., 2011; Koch et al., 2009 dan Konturek et al., 2007). 
Hormon melatonin adalah hormon yang memiliki fungsi sangat banyak, diantaranya adalah melindungi sel, mengatur regulasi sistem pencernaan (di usus dan pankreas), pertahanan tubuh (sistem imun), peredaran darah, hormon seks, dan lain-lain sebagaimana disajikan pada gambar 2. Tidur pada jam yang tepat dan mematikan lampu sebelum tidur sangat membantu menormalkan mekanisme jam biologis (circardian rhytms). Circadian rhythms adalah jam biologis internal manusia normal. Jam ini mengatur banyak hal terkait aktivitas dan fungsi diri kita, di antaranya pola tidur, temperatur tubuh, metabolisme, kesadaran, tekanan darah, detak jantung, tingkat hormon, dan sebagainya (Hardeland et al., 2011)

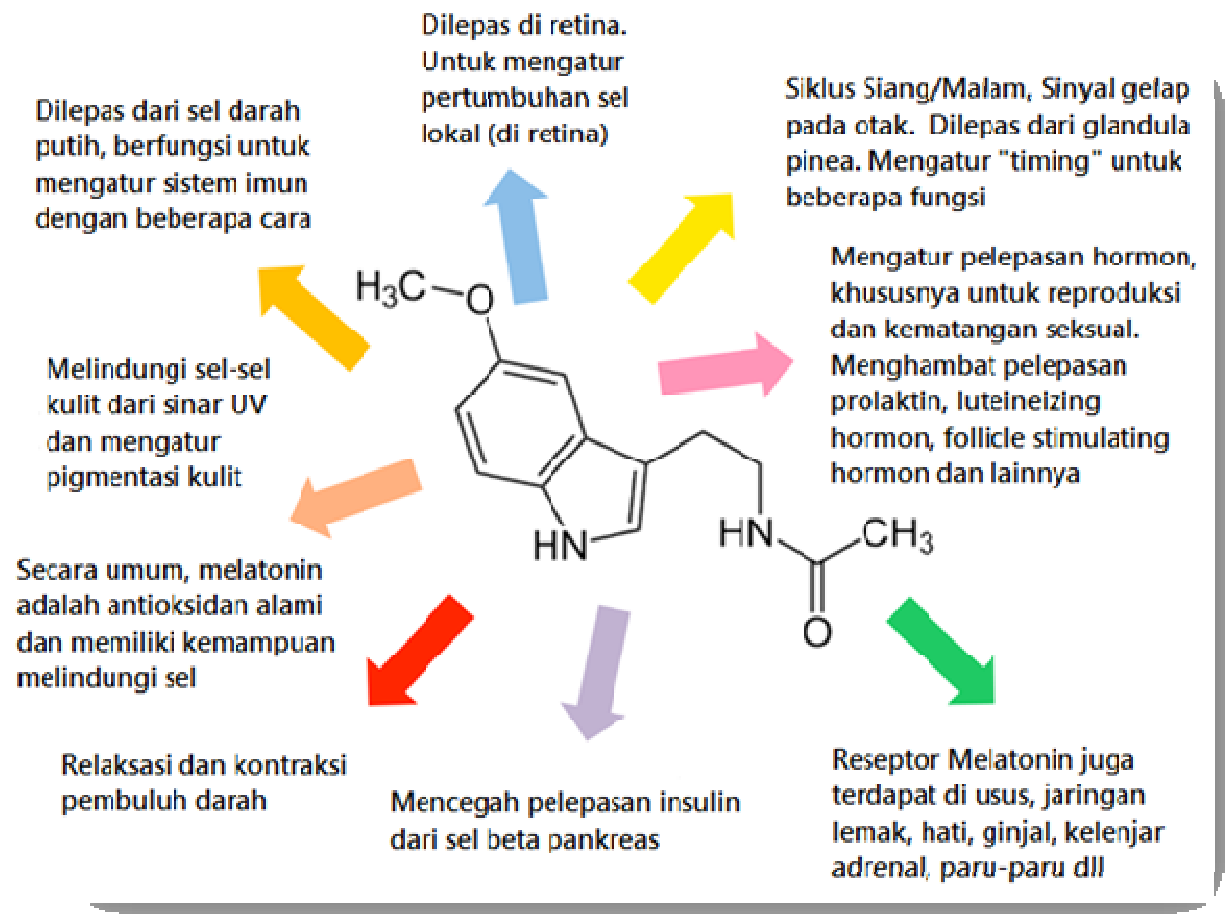

Gambar 2. Peran hormon melatonin yang sangat besar dalam tubuh, dirangkum dari Hardeland et al. (2011)

Hormon melatonin ini akan bekerja sempurna dalam kegelapan (ketika mata tidak menangkap cahaya) pada fase-fase tertentu jam biologis (Circardian rhytm). Gaya tidur dalam keadaan terang akan menyebabkan penghambaran sekresi melatonin dalam otak sebagaimana gambar 3. 


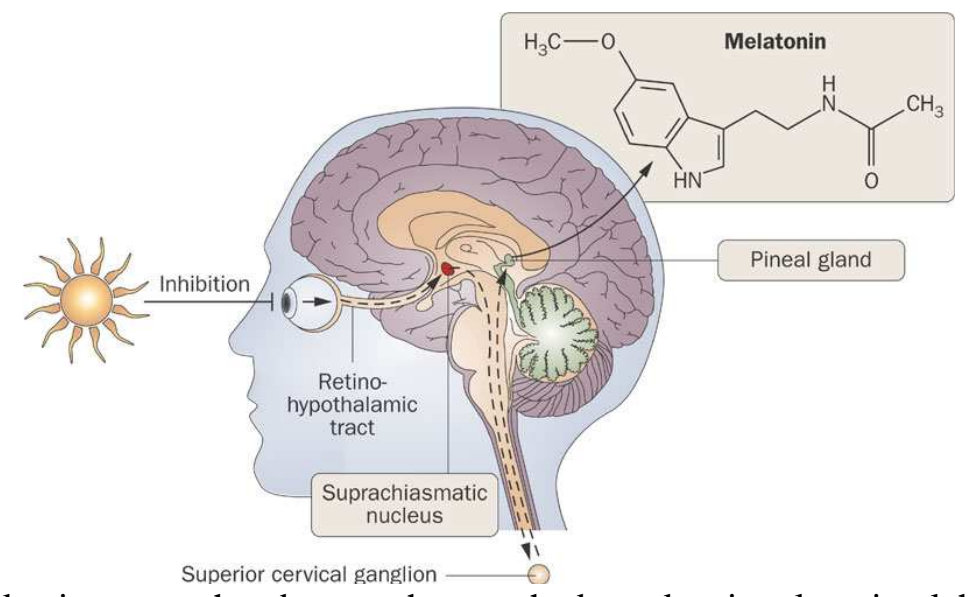

Gambar 3. Mekanisme penghambatan cahaya terhadap sekresi melatonin oleh kelenjar pineal yang terjadi diawali dari jalur saraf di retina dan melewati suprachiasmatic nukleus di otak, untuk mencapai pinealocytes melalui saraf adrenergik dan reseptor adrenergik, dan kemudian ke syaraf tepi (Koch et al., 2009). Gambar diadopsi dari Konturek et al. (2007).

Selama masa gelap, Circardian rhytm berjalan dengan bebas dan sempurna, menyebabkan bertambahnya konsentrasi melatonin dalam tubuh (Koch et al., 2009). Penghambatan sekresi melatonin pada malam hari akan sangat berbahaya, baik karena paparan cahaya saat tidur, maupun melakukan pekerjaan di malam hari diluar jam biologis yang semestinya, hal ini dapat memicu timbulnya penyakit seperti diabetes, kegemukan, dan kanker (Rea dan Figurio, 2013). Ketidakteraturan jam tidur dan paparan cahaya di malam hari pada jam tidur juga berpotensi menyebabkan penyakit kanker kolon, prostat, dan payudara (Blask, 2009).

\section{KESIMPULAN}

Petunjuk Nabi diantaranya tentang tata cara berwudhu, mandi, menggosok gigi, dan menanam pohon erat kaitannya dengan konservasi air, sedangkan ajaran berpuasa, berjalan kaki untuk ke masjid, mematikan lampu tidur, dan sebagainya sangat memiliki peran yang nyata dalam konservasi air dan energi. Meskipun istilahnya bukan konservasi, namun prinsip, semangat dan praktek konservasi telah nyata dilakukan Rasulullah Shallallahu 'alaihi wasallam dan sahabatnya melalui praktek hidup sehari-hari. Artinya konservasi air dan energi dapat digalakkan dengan kembali menghidupkan Sunnah Nabi Shallallahu 'alaihi wasallam.

\section{DAFTAR PUSTAKA}

Abdel-Haleem, M. 1989. Water in the Qur'ān. Islamic Quarterly, 33(1): 34-50.

Adriyati, P. 2011. Pengaruh Pemberian Larutan Ekstrak Siwak (Salvadora Persica) Terhadap Pembentukan Plak Gigi. Artikel Karya Tulis Ilmiah. Fakultas Kedokteran Universitas Diponegoro. Semarang.

Ahmad, H. 2012. Biological Activities of Salvadora persica L. (Meswak). Medicinal \& Aromatic Plants, 02(04): 2-6. doi:10.4172/2167-0412.1000129

Ahmad, H. 2011. Islam and Water The Hajjar (r.a.) Story and Guide. Global One: London.

Al-Khalafi, AAB. 2011. Al-Wajiz Fi Fiqhis Sunnah wal Kitabil 'Aziz.: Ensiklopedia Fiqih Islam dalam Al-Qur'an dan As Sunnah As Shahihah. Penerjemah: Ma'ruf Abdul Jalil. Pustaka As Sunnah. Jakarta.

Al-Bayati, F.A. and Sulaiman, K. D. 2008. In Vitro Antimicrobial Activity of Salvadora persica L . Extracts Against Some Isolated Oral Pathogens in Iraq. Turk J Biol 32: 5762.

Al-Jazairi, A.B.J. 2010. Minhajul Muslim At Tob'ah Tsani (Cetakan kedua). Daar Al Aqidah. Iskandariyah. Mesir.

Almas, K. and Al-Zeid, Z. 2004. The immediate antimicrobial effect of a toothbrush and miswak on cariogenic bacteria: A clinical study. J Contemp Dent Pract (1): 1-8.

Almas, K. 2002. The Effect of Salvadora Persica Extract (Miswak) and Chlorahexidine Gluconate on Human Dentin: A SEM 
Study. The Journal of Contemporary Dental Practice 3(3): 27-35.

Arika, D.M. 2012. Kajian Pola Konsumsi Air Bersih Rumah Tangga Di Kelurahan Setiamanah, Kota Cimahi Sebagai Masukan Bagi Upaya Konversi. Undergraduate Theses. Regional and City Planning Study Programme. Institut Teknologi Bandung. Bandung

Blask, D. E. 2009. Melatonin, sleep disturbance and cancer risk. Sleep Medicine Reviews. 13(4): doi:10.1016/j.smrv.2008.07.007

Gilli, F. 2002. Islam, Water Conservation and Public Awareness Campaigns. University of Ca' Foscari, Venice, Italy.

Hardeland, R., Cardinali, D., Srinivasan, V., Spence, D., Brown, G., \& Pandi-Perumal, S. 2011. Melatonin-A pleiotropic, orchestrating regulator molecule. Progress in Neurobiology, $93(3), \quad 350-384$ DOI:10.1016/j.pneurobio.2010.12.004

Hossain, M. Z. 2012. Fasting in Islam $\square$ : Its Excellence. Benefits and Use for Sustainable Department of Operations Management and Business Statistics. 3(3): 184-190.

Kementerian ESDM. 2011. Pemborosan Energi 80 Persen Faktor Manusia. http://www.esdm.go.id/berita/listrik/39listrik/4448-pemborosan-energi-80-persenfaktor-manusia-.html. Diakses pada 9 Mei 2014 Pukul 19:29

Khaled, H.A. and Khalid H.F.. Muslim Green Guide to Muslim Green Guide to reducing Climate Change. LifeMakers UK \& Islamic Foundation for Ecology and Environmental Sciences

Koch, B.C., Negtegaal, J.E, Gerard, A.K. and teer We, P.M. 2009. Circadian sleepwake rhythm disturbances in end-stage renal disease. Nature Reviews Nephrology. 5:407-416. doi:10.1038/nrneph.2009.88

Konturek, S. J., Konturek, P. C., Brzozowski, T. and Bubenik, G. A. 2007. Role of melatonin in upper gastrointestinal tract. $J$ Physiol Pharmacol. 58 Suppl 6:23-52.

McKay, J.E. (Editor). 2013. Integrating Religion Within Conservation: Islamic Beliefs and Sumatran Forest Management. Durrell Institute of Conservation and Ecology. University of Kent. UK
Muadz, M. 2014. Hari Ini, Islam Jadi Agama Terbesar di Dunia. http://www.republika.co.id/berita/duniaislam/hikmah/14/01/13/mzbetu-hari-iniislam-jadi-agama-terbesar-di-dunia. Diakses Pada 16 mei 2014 Pukul 09:44.

Nurmiyanto, A. 2012. Daur Ulang air Wudhu (Fatwa MUI) tentang Air Daur Ulang http://awaluddin.web.id/archives/436. Diakses pada 2 Mei 2014 Pukul 10:43

Pratiwi, R. 2005. Perbedaan daya hambat terhadap Streptococcus mutans dari beberapa pasta gigi yang mengandung herbal. 64-67. http://www.journal.unair.ac.id/filerPDF/D ENTJ-38-2-05.pdf. Diakses pada 4 Mei 2014 Pukul 11:33

Rea, M.S. and Figueiro, M. G. 2013. A Working Threshold for Acute Nocturnal Melatonin Suppression from "White" Light Sources used in Architectural Applications. $J$ Carcinogene Mutagene 4(3):1-6. http://dx.doi.org/10.4172/21572518.1000150

Shaykh, B., and Mahmood, T. 2007. Multidimensional Benefits of Fasting. Released by www.marifah.net. Diakses pada 10 Mei 2014 Pukul 10:21

Wickström, L. 2010. Islam and water $\square$ : Islamic guiding principles on water management. FIIA Reports: 98-108. 